\title{
Invasive mechanical ventilation in COVID- 19 patient management: the experience with 469 patients in Wuhan
}

\author{
Jing Hua ${ }^{1 \dagger}$, Chenchen Qian ${ }^{2 \dagger}$, Zhibing Luo ${ }^{1 \dagger}$, Qiang $\mathrm{Li}^{1^{*}}$ and Feilong Wang ${ }^{1 *}$ (D)
}

Dear Editor,

Since the first case of COVID-19 was reported in Wuhan, this new respiratory disease has evolved rapidly and been found in almost all the countries in the world. From our clinical experiences during managing COVID19 patients, we observed an extremely high fatality rate in invasive ventilation (IV) patients which was astonishing and unexpected.

To validate our assumption, we collected and analyzed the data of 469 ICU COVID-19 patients who were hospitalized from February 2020 to the end of March in 13 ICUs in Wuhan. At the time of data collection, all of the patients were either discharged or deceased (Table 1).

Clinical features, laboratory results on admission, and outcomes are shown in Table 2. We found that the mortality rate in the IV group was $92 \%$, compared to the other two groups $(6.4 \%$ in the NV group, $40.8 \%$ in the NIV group). Furthermore, patients in the IV group developed a higher rate of severe comorbidities such as acute kidney injury (AKI) which required continuous renal replacement therapy (CRRT) (26.5\%) compared to the NV (2.9\%) and NIV (5.3\%) groups. Moreover, 10 patients $(8.8 \%)$ in the IV group received ECMO implementation.

The mean age in the IV group was 71, which was significantly higher than the other two groups (67 in both the NIV group and NV group, $P=0.03$ ). There were no significant differences in comorbidities on admission except chronic obstructive pulmonary disease (COPD). Interestingly, there were even more cases of COPD in the NIV group $(31,20.7 \%)$ than in the IV group (8, 7.1\%). This could be explained that physicians tend to avoid intubation in chronic lung disease patients due to concern of barotrauma and higher DNR/DNI ratio in those patients. From laboratory results, significantly higher white blood cell count, lower lymphocyte count and platelet count, and higher CRP, AST, ALT, and total bilirubin are presented in the IV group than the other two groups on admission. SOFA scores in the IV and NIV groups were also significantly higher than the NV group. There were no significant differences in Scr among these groups on admission though. We can tell from the data that the patients in the IV group were older with a higher rate of hyperinflammation status on admission compared to the other two groups. These factors may lead to the rapid progress of respiratory failure and fatal outcome eventually [1].

Researchers worldwide also start to realize that IV may not improve the mortality in COVID-19 patients [2, $3]$. We have to admit that some of the COVID-19 patients who developed progressive worsening respiratory distress were refractory to NIV. Intubation is inevitable in those cases. However, sometimes physicians can be rushed to intubation. It has been reported that intubation can be successfully avoided by HFNO $[4,5]$.

As we all know, IV can cause a lot of complications including hypotension, ventilator-related infection, volume imbalance, and sedation-related delirium. The decision of intubation mostly based on clinical judgments and varies from case to case. There is a notion that NIV

\footnotetext{
* Correspondence: liqressh@hotmail.com; dr.feilongwang@gmail.com

† Jing Hua, Chenchen Qian and Zhibing Luo contributed equally to this work.

${ }^{1}$ Department of Pulmonary and Critical Care Medicine, Shanghai East

Hospital, Tongji University School of Medicine, Shanghai, China

Full list of author information is available at the end of the article
} 
Table 1 Centers and study periods

\begin{tabular}{lll}
\hline Centers & Study period & No. of cases \\
\hline Huoshenshan Hospital (2 ICUs) & February 2 to March 31 & 118 \\
Leishenshan Hospital (2 ICUs) & February 23 to March 31 & 41 \\
Guanggu Hospital (2 ICUs) & February 21 to March 25 & 40 \\
Taikang Hospital (2 ICUs) & February 11 to March 21 & 42 \\
Zhongfaxincheng Hospital (3 ICUs) & February 8 to March 15 & 147 \\
Wuhan Fifth Hospital (1 ICU) & February 20 to March 31 & 21 \\
Union Hospital (1 ICU) & February 15 to March 31 & 60 \\
\hline
\end{tabular}

Table 2 Clinical features, laboratory results on admission, and outcomes of the study patients

\begin{tabular}{|c|c|c|c|c|c|}
\hline & $\begin{array}{l}\text { All } \\
(n=469)\end{array}$ & $\begin{array}{l}\text { No ventilation } \\
(n=204)\end{array}$ & $\begin{array}{l}\text { Invasive ventilation } \\
(n=113)\end{array}$ & $\begin{array}{l}\text { Noninvasive ventilation } \\
(n=152)\end{array}$ & $P$ \\
\hline$\overline{\text { Age }}$ & $68 \pm 13$ & $67 \pm 15$ & $71 \pm 10$ & $67 \pm 13$ & 0.030 \\
\hline Sex & & & & & 0.034 \\
\hline Male & $266(56.7)$ & $108(52.9)$ & $76(67.3)$ & $82(53.9)$ & \\
\hline Female & $203(43.3)$ & $96(47.1)$ & $37(32.7)$ & $70(46.1)$ & \\
\hline \multicolumn{6}{|l|}{ Comorbidities, no. (\%) } \\
\hline Hypertension & $240(51.4)$ & $99(48.5)$ & $56(49.6)$ & $85(56.7)$ & 0.288 \\
\hline Diabetes & $110(23.6)$ & $41(20.1)$ & $28(24.8)$ & $41(27.3)$ & 0.268 \\
\hline Coronary artery disease & $84(18.0)$ & $44(21.6)$ & $20(17.9)$ & $20(13.3)$ & 0.137 \\
\hline Chronic obstructive lung disease & $52(11.1)$ & $13(6.4)$ & $8(7.1)$ & $31(20.7)$ & $<0.001$ \\
\hline Chronic kidney disease & $42(9.0)$ & $21(10.3)$ & $8(7.1)$ & $13(8.7)$ & 0.623 \\
\hline \multicolumn{6}{|l|}{ Laboratory results on admission } \\
\hline White blood cell count, $\times 10^{9} / \mathrm{L}$ & $9.4 \pm 6.0$ & $6.9 \pm 3.6$ & $12.7 \pm 8.0$ & $10.2 \pm 5.2$ & $<0.001$ \\
\hline Neutrophil count, $\times 10^{9} / \mathrm{L}$ & $8.5 \pm 9.2$ & $5.7 \pm 6.4$ & $12.6 \pm 11.9$ & $8.6 \pm 5.1$ & $<0.001$ \\
\hline Lymphocyte count, $\times 10^{9} / \mathrm{L}$ & $0.9 \pm 0.6$ & $1.0 \pm 0.5$ & $0.7 \pm 0.8$ & $0.9 \pm 0.6$ & 0.002 \\
\hline NLR (neutrophil/lymphocyte ratio) & $13.1 \pm 13.5$ & $7.8 \pm 9.3$ & $21.3 \pm 16.0$ & $13.9 \pm 13.0$ & $<0.001$ \\
\hline Monocytes, count, $\times 10^{9} / \mathrm{L}$ & $0.5 \pm 0.4$ & $0.5 \pm 0.6$ & $0.5 \pm 0.4$ & $0.5 \pm 0.3$ & 0.947 \\
\hline Platelet count, $\times 10^{9} / \mathrm{L}$ & $214 \pm 112$ & $225 \pm 97$ & $180 \pm 123$ & $223 \pm 118$ & 0.001 \\
\hline C-reactive protein (mg/L) & $78.7 \pm 83.6$ & $47.0 \pm 51.4$ & $116.1 \pm 94.2$ & $92.6 \pm 93.8$ & $<0.001$ \\
\hline Procalcitonin (ng/ml) & $1.9 \pm 8.8$ & $0.7 \pm 4.7$ & $2.8 \pm 10.5$ & $2.7 \pm 10.9$ & 0.078 \\
\hline $\mathrm{ALT}(\mathrm{U} / \mathrm{L})$ & $47.1 \pm 95.2$ & $31.6 \pm 30.2$ & $80.8 \pm 179.1$ & $44.3 \pm 40.9$ & $<0.001$ \\
\hline AST (U/L) & $60.2 \pm 227.0$ & $31.2 \pm 25.0$ & $110.7 \pm 429.4$ & $60.9 \pm 138.3$ & 0.019 \\
\hline Total bilirubin $(\mu \mathrm{mol} / \mathrm{L})$ & $14.7 \pm 11.5$ & $11.0 \pm 5.7$ & $18.1 \pm 13.2$ & $16.8 \pm 14.1$ & $<0.001$ \\
\hline Direct bilirubin $(\mu \mathrm{mol} / \mathrm{L})$ & $8.1 \pm 7.5$ & $5.0 \pm 5.1$ & $9.9 \pm 9.2$ & $10.6 \pm 7.3$ & $<0.001$ \\
\hline Albumin (g/L) & $32.0 \pm 5.6$ & $32.7 \pm 4.6$ & $30.1 \pm 7.0$ & $32.4 \pm 5.4$ & $<0.001$ \\
\hline D-dimer ( $\mu \mathrm{g} / \mathrm{mL})$ & $5.9 \pm 11.9$ & $3.1 \pm 5.3$ & $13.2 \pm 20.5$ & $4.5 \pm 7.0$ & 0.276 \\
\hline Glucose (mmol/L) & $8.7 \pm 4.7$ & $7.1 \pm 3.3$ & $10.3 \pm 6.8$ & $9.5 \pm 3.9$ & $<0.001$ \\
\hline Serum creatine $(\mathrm{Scr})(\mu \mathrm{mol} / \mathrm{L})$ & $128.3 \pm 190.7$ & $124.5 \pm 197.5$ & $119.2 \pm 165.2$ & $140.2 \pm 199.9$ & 0.636 \\
\hline SOFA score on day 1 & $4.2 \pm 3.1$ & $2.2 \pm 2.2$ & $6.0 \pm 3.0$ & $5.5 \pm 2.7$ & $<0.001$ \\
\hline Continuous renal replacement therapy (CRRT), no. (\%) & $44(9.4)$ & $6(2.9)$ & $30(26.5)$ & $8(5.3)$ & $<0.001$ \\
\hline Extracorporeal membrane oxygenation (ECMO), no. (\%) & $10(3.1)$ & $0(0.0)$ & $10(8.8)$ & $0(0.0)$ & $<0.001$ \\
\hline Length of hospital stay (days) & $20.4 \pm 13.2$ & $27.3 \pm 14.7$ & $17.9 \pm 12.3$ & $16.1 \pm 9.6$ & $<0.001$ \\
\hline Mortality, no. (\%) & 179 (38.2) & $13(6.4)$ & $104(92.0)$ & $62(40.8)$ & $<0.001$ \\
\hline
\end{tabular}


causes wide-spread dispersion of aerosol thus increases the risk of transmission to healthcare workers. This could be one of the reasons that encourages physicians to choose IV over NIV among clinical decisions [5].

In conclusion, from our data in Wuhan, COVID-19 patients who were invasively ventilated exhibited pessimistic outcomes. This suggests that early intubation may not help patients but instead, make things head towards the wrong direction. We should try to avoid IV and utilize NIV at the early stage of respiratory failure until IV is inevitable [6]. It is time for physicians to rethink the threshold of intubation in COVID-19 management.

\begin{abstract}
Abbreviations
Covid-19: Coronavirus disease 2019; NV: No ventilation (nasal cannula oxygen); NIV: Noninvasive ventilation (BiPAP, CPAP, or high-flow nasal oxygen); IV: Invasive ventilation; HFNO: High-flow nasal oxygen
\end{abstract}

\section{Acknowledgements}

None.

\section{Authors' contributions}

Jing Hua and Zhibing Luo contributed to the collection and analysis of the clinical data. Chenchen Qian drafted the manuscript and critically reviewed the manuscript. Feilong Wang and Qiang Li conceptualized the study design and contributed to the analysis of the clinical data. The authors read and approved the final manuscript.

\section{Funding}

This work was supported by the National Key Research and Development Project of the Ministry of Science and Technology, China (2018YFC1313700) and the "Gaoyuan" project of Pudong Health and Family Planning Commission (PWYgy2018-6).

\section{Availability of data and materials}

The datasets used and/or analyzed during the current study are available from the corresponding author on reasonable request.

\section{Ethics approval and consent to participate}

The study was approved by the Shanghai East Ethics Committee.

\section{Consent for publication}

Written informed consent was waived by the Ethics Committee due to the retrospective nature of this study and rapid emergence of this infectious disease.

\section{Competing interests}

All authors declare no competing interests.

\section{Author details}

${ }^{1}$ Department of Pulmonary and Critical Care Medicine, Shanghai East Hospital, Tongji University School of Medicine, Shanghai, China. ${ }^{2}$ Department of Internal Medicine, UPMC Pinnacle Hospital, Harrisburg, PA, USA.

Received: 14 May 2020 Accepted: 28 May 2020

Published online: 16 June 2020

\section{References}

1. Mehta P, McAuley DF, Brown M, Sanchez E, Tattersall RS, Manson JJ, HIh Across Speciality Collaboration UK. COVID-19: consider cytokine storm syndromes and immunosuppression. Lancet. 2020;395(10229):1033-4.

2. Grasselli G, Zangrillo A, Zanella A, Antonelli M, Cabrini L, Castelli A, Cereda D, Coluccello A, Foti G, Fumagalli R, et al. Baseline characteristics and outcomes of 1591 patients infected with SARS-CoV-2 admitted to ICUs of the Lombardy region, Italy. JAMA. 2020;323(16):1574-81.

3. Wang K, Zhao W, Li J, Shu W, Duan J. The experience of high-flow nasal cannula in hospitalized patients with 2019 novel coronavirus-infected pneumonia in two hospitals of Chongqing, China. Ann Intensive Care. 2020; 10(1):37.

4. Rochwerg B, Brochard L, Elliott MW, Hess D, Hill NS, Nava S, Navalesi PMOTSC, Antonelli M, Brozek J, Conti G, et al. Official ERS/ATS clinical practice guidelines: noninvasive ventilation for acute respiratory failure. Eur Respir J. 2017;50(2):1602426.

5. Arulkumaran N, Brealey D, Howell D, Singer M. Use of non-invasive ventilation for patients with COVID-19: a cause for concern? Lancet Respir Med. 2020.

6. Li J, Fink JB, Ehrmann S. High-flow nasal cannula for COVID-19 patients: low risk of bio-aerosol dispersion. Eur Respir J. 2020.

\section{Publisher's Note}

Springer Nature remains neutral with regard to jurisdictional claims in published maps and institutional affiliations.

\section{Ready to submit your research? Choose BMC and benefit from:}

- fast, convenient online submission

- thorough peer review by experienced researchers in your field

- rapid publication on acceptance

- support for research data, including large and complex data types

- gold Open Access which fosters wider collaboration and increased citations

- maximum visibility for your research: over $100 \mathrm{M}$ website views per year

At BMC, research is always in progress.

Learn more biomedcentral.com/submissions 